\title{
GRAFITAGEM REBELDE: traços de uma análise cartográfica no Recife Antigo
}

Rebellious graffiti: lines of a cartographical analysis at "Recife Antigo" Grafiti Rebelde: rasgos de una análisis cartográfica en "Recife Antigo"

Hérrisson Fábio de Oliveira Dutra ${ }^{1}$

Ana Carmen Palhares ${ }^{2}$

Sérgio Carvalho Benício de Mello ${ }^{3}$

\section{RESUMO}

Este artigo se propóe a discutir a produção visual de grafiteiros no Recife Antigo, bairro histórico da capital pernambucana, com o intuito de identificar como o grafite dialoga com questóes de pertencimento territorial, legitimidade e identidade. Tem-se, como pano de fundo, a contenda do poder público entre a promoçâo do bem estar social e o atendimento dos interesses do capital no planejamento urbano das cidades. Para isso, foram apresentadas proposiçóes sobre o direito à cidade, contempladas por David Harvey, Henri Lefebvre, Jean Lojkine entre outros. Como método, a pesquisa se inspirou nas diretrizes do método cartográfico rizomático descrito pelos filósofos franceses Gilles Deleuze e Felix Guattari. De 47 grafites identificados, 11 foram selecionados e organizados em 4 mapas que contemplam a estética da grafitagem, o anticapitalismo, a insustentabilidade da exploraçâo de recursos naturais e a exploração sexual de menores. Ao término, abre-se a possibilidade para novos e inesgotáveis entendimentos dos mapas apresentados, numa compreensão de que, a cada novo olhar, a arte da grafitagem evoca diferentes questóes nas lutas de classe de base urbana.

PALAVRAS-CHAVE: Cidade. Urbano. Grafitagem. Arte Urbana. Capitalismo. Cartografia.

1 Doutor em Administração pela Universidade Federal de Pernambuco. Analista em Ciência \& Tecnologia da Fundação Joaquim Nabuco, atuando com políticas públicas de educação e cultura na Diretoria de Memória, Educação, Cultura e Arte. Pesquisador em arte urbana, com ênfase em grafismos, como reflexo de problemas existentes nas metrópoles brasileiras. E-mail: hfdutra@uol.com.br.

2 Desenvolve sua pesquisa de Doutorado em Estudos Culturais, junto às Universidades do Minho e de Aveiro em Portugal. É servidora do da Fundação Joaquim Nabuco, órgão vinculado ao Ministério da Educação do Brasil, onde ocupa o cargo de Analista em Ciência e Tecnologia Sênior. Atua no campo da Cultura Contemporânea com ênfase em Arte-Educação. Coordenou projetos em Artes Visuais e Cinema Educaçấo. E-mail: anacarmenpalhares@gmail.com.

3 Professor associado 4 da Universidade Federal de Pernambuco. Bolsista de produtividade em pesquisa nível 1D do CNPq. E-mail: sergio.benicio@gmail.com. 


\begin{abstract}
This article proposes to discuss the graffiti artists' visual production at "Recife Antigo", the historical center of the capital of Pernambuco state, aiming to identify the way the graffiti work addresses questions related to territorial belonging, legitimacy and identity. As a background, there is the public power dispute between the promotion of welfare and the capital interests on urban planning of cities. For that purpose, propositions regarding the right to the city contemplated by the British geographer David Harveyin his book Cidades Rebeldes (Rebellious Cities) have been presented. As amethod, the rhizomatic cartography described by the French philosophers Gilles Deleuze and Feliz Guattari has been used. From 47 graffiti identified, 11 of them have been selected and organized in 4 charts contemplating items such as graffiti aesthetic,anti-capitalism, nonsustainability of natural resource exploitation and sexual exploitation of children. Finally, the possibility to new and inexhaustible understandings on the charts presented is opened, in a perception that, in every newoutlook, the graffiti art evokes different questions in urban-based class struggles.
\end{abstract}

KEYWORDS: City. Urban. Graffiti. Urban Art. Capitalism. Cartography.

\title{
RESUMEN
}

Este artículo se propone a discutir la producción visual de los artistas de graffiti en Recife Antigo, barrio histórico de la capital de Pernambuco, con el propósito de identificar cómo el graffiti dialoga con cuestiones de pertenencia territorial, identidad y legitimidad. Como telón de fondo, es el argumento del gobierno entre la promoción del bienestar social y los intereses del capital en la planificación urbana de las ciudades. Para ello, se presentaron propuestas sobre el derecho a la ciudad, contemplado por David Harvey, Henri Lefebvre, Jean Lojkine, entre otros. Como método, la inv`estigación se inspiró en las directrices del método cartográfico rizomático descrito por los filósofos franceses Gilles Deleuze y Felix Guattari. De 47 graffitis identificados, 11 fueron seleccionados y organizados en 4 mapas que contemplan la estética del graffiti, la insostenibilidad de la explotación de recursos naturales y la explotación sexual de menores. $\mathrm{Al}$ término, se abre la posibilidad para entendimientos nuevos e inagotables de los mapas presentados, en una comprensión de que, a cada nueva imagen, el arte del graffiti evoca diversas cuestiones en las luchas de clase de base urbana.

PALABRAS CLAVE: Ciudad. Urbano. Graffiti. Arte urbana. Capitalismo. Cartografía. 


\section{O RECIFE ANTIGO: uma ilha que reproduz uma cidade}

"Ficar bem desenhado só pra ser bem lembrado

Risco do erro, mal visto, mal quisto e mal olhado

Não é só um sinal de quem passou por maus bocados

Mas essa daqui me traz uma boa lembrança, não preciso esconder...”

Cicatriz (Nação Zumbi)

O Recife Antigo, também denominado como Bairro do Recife, é a localidade mais antiga da capital pernambucana. Da sua origem aos dias atuais, essa ilha já sofreu inúmeras transformaçóes, fazendo com que a sua área, depois de sucessivos aterros, passasse a ser dez vezes maior que a original (CAMPELO, 2008).

Nas últimas décadas, o poder público tem promovido uma série de ações de requalificação urbana no bairro: recuperação patrimonial com projetos de restauração, reforma e novas ocupaçôes de espaços públicos, mudança no trânsito com medidas para redução de velocidade de automóveis, rua exclusiva para pedestres e ciclovia; investimento em infraestrutura tecnológica para atração de empreendimentos e realização de açóes sociais e de lazer para residentes e turistas. Como consequência, o Recife Antigo tem atraído novos e maiores públicos.

No cotidiano do bairro, durante a semana, ele é frequentado pelos moradores da Comunidade do Pilar $^{4}$ e por trabalhadores de órgãos públicos e empreendimentos comerciais ali situados. Identifica-se também turistas que visitam pontos históricos e equipamentos culturais. No turno da noite, o bairro assume ares boêmios, com o funcionamento de bares, boates e restaurantes para públicos de diferentes classes sociais.

Nos antigos armazéns, situados na margem leste da ilha, a reforma realizada com recursos públicos permitiu que grandes empreendimentos gastronômicos e de entretenimento se instalassem, atraindo um público de alto poder aquisitivo ao bairro. Na Praça do Marco Zero, um apêndice entre os armazéns, patinadores, skatistas e jovens estudantes reúnem-se em tribos, sentam-se em círculo no piso da praça para comer e beber, fazem malabarismos e acrobacias sobre rodas, ensaiam maracatu e outras expressóes artísticas e culturais.

Nos finais de semana, em especial no último domingo de cada mês, há o projeto municipal "Recife Antigo de Coração", cujo objetivo é fazer com que o bairro se torne um grande parque urbano, onde as pessoas pos-

4 Conjunto habitacional popular, situado no Recife Antigo a poucos metros da Prefeitura, cujos moradores vivem em condiçóes precárias (SANTOS, 2010; GIUSTINA, 2010). 
sam circular com liberdade. Concentrado em três polos (infantil, cultural e esportivo), ele é dedicado a todas as idades com atividades durante o dia inteiro, além de apresentaçóes culturais, blocos itinerantes, aluguel de equipamentos esportivos, rampas de skate e área reservada com atendimento para as crianças (RECIFE ANTIGO DE CORAÇÃO, 2013). Além desse, outros projetos como o "Olha! Recife" e "Ciclofaixa de Turismo e Lazer" tem mudado a dinâmica do bairro. O que antes era restrito a um calendário de datas comemorativas, agora tem sido regular nos finais de semana. Como resultado, o Recife Antigo vem atraindo nos sábados e domingos mais de 40 mil pessoas que participam de práticas esportivas, brincadeiras e apresentaçóes culturais (NE10, 2014). Porém, as melhorias promovidas no Recife Antigo, táo bem alardeadas pelo poder público, coexistem com problemas que já estão se tornando crônicos no bairro.

A Comunidade do Pilar que, apesar de estar localizada também na ilha, parece assistir, a distância, essa nova realidade vivida no bairro. Seus moradores não se sentem incluídos e contemplados nas políticas públicas de requalificação urbana que estão sendo implantadas. Na verdade, eles se sentem paralisados no tempo, ainda à espera da implementação do Projeto de Requalificação Urbana e Inclusão Social da Comunidade do Pilar - PRUISCP, lançado pela Prefeitura do Recife desde 2007 e dotado de recursos municipais e federais oriundos do Plano de Aceleração do Crescimento (NERY e CASTILHO, 2008; NERY e SÁ, 2009; NERY, 2012). Recentemente, diante da inércia do poder público com o avançar das obras, o Ministério Público Federal exigiu que a Prefeitura do Recife finalizasse as obras até o dia 30 de setembro de 2016 (G1, 2016).

A violência do Recife Antigo também tem sido manchete nos jornais locais. Em especial aos domingos, pais e filhos que frequentavam o bairro pela manhã com roupas leves para caminhadas ou pedaladas cedem espaço, no cair da tarde, a jovens e adultos em busca de outras atividades de lazer, dentre elas a prostituição e o consumo de drogas como maconha, cocaína, loló e crack, gerando um clima de tensão e violência com frequentes arrastôes (G1, 2014; BLOG DA FOLHA, 2015; FOLHA-PE, 2016). É quando a sensação de segurança começa a dar lugar à instabilidade, tornando o bairro - antes considerado ensolarado, seguro e familiar - num ambiente perigoso e violento.

Ainda de acordo com essas matérias, a maior concentração de atos ilícitos ocorre em especial nas ruas estreitas próximas à Ponte Giratória, no sul da ilha, área que compreende os Polos Alfândega/Madre Deus e Bom Jesus, onde muitas ruas ainda não foram contempladas pelo Plano de Revitalização do Bairro do Recife (1993) (Figura 1). Essa área abriga um conjunto edificado de valor cultural reconhecido e onde deveriam ser promovidas as recupera- 
çôes em termos de infraestrutura, reciclagem dos imóveis e dinamização das atividades (PREFEITURA MUNICIPAL DO RECIFE, 2001; LEAL, 2003; NERY e CASTILHO, 2008).

Figura 1: Mapa do Plano de Revitalização do Bairro do Recife, 1993.

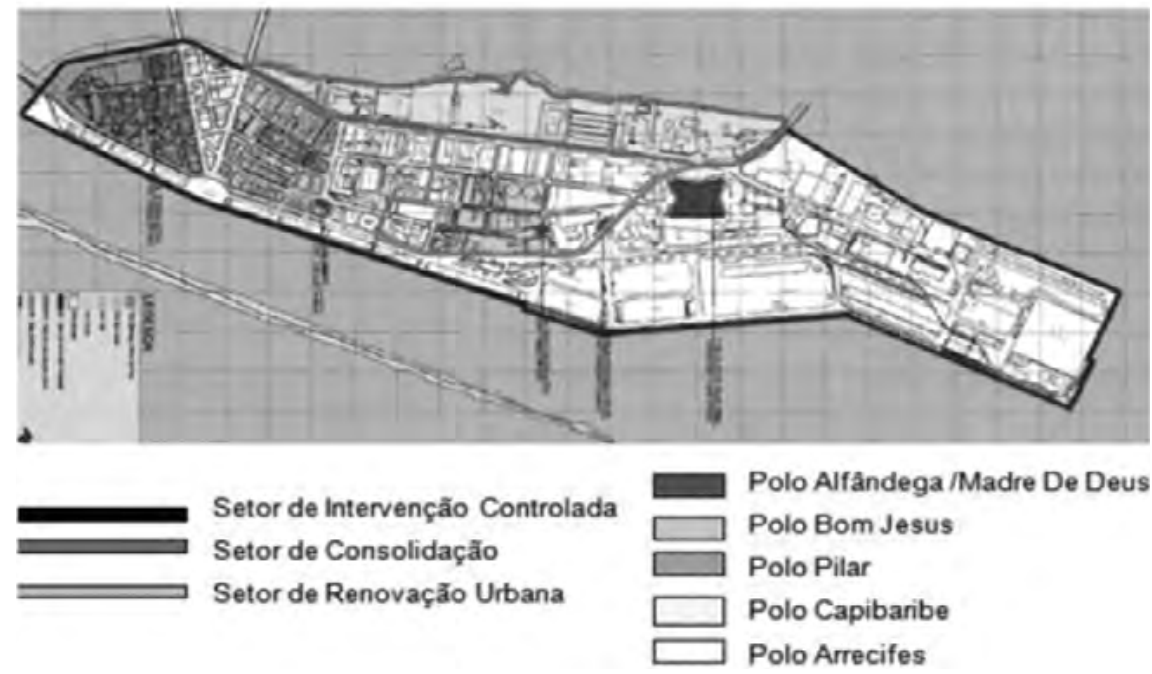

Fonte: NERY e CASTILHO, 2008.

Nelas, alguns casarios com estabelecimentos comerciais como bares, escritórios e galerias de arte mantem-se em bom estado, compartilhando o espaço com tantos outros abandonados ou ocupados por famílias que não possuíam moradia. Nas paredes externas desses prédios, em meio ao lixo e ao desgaste natural do tempo, pode-se encontrar extensos, numerosos e diversificados grafites que ainda dão vida e cor a uma área degradada, pouco iluminada, rotulada como violenta pela imprensa, esquecida pelo poder público e desinteressante para a exploração imobiliária.

Percebe-se, então, uma situação conflituosa. Se, por um lado, o poder público busca atender o interesse da coletividade, revitalizando o patrimônio histórico do Recife Antigo e promovendo açôes sociais, de lazer e diversão em suas ruas e praças; por outro, prioriza-se as demandas capitalistas, gerando guetos de alto luxo com a instalação de modernos empreendimentos nos antigos armazéns reformados. Em uma mesma ilha, sob a atmosfera de uma tensão silenciada, é possível encontrar esgoto a céu aberto nas vielas da Comunidade do Pilar, infraestrutura de alta tecnologia para os empreendimentos do Porto Digital ${ }^{5}$, famílias se divertindo em ciclofaixas, como também

5 Iniciativa privada, do Governo do Estado de Pernambuco e de universidades da região que abriga hoje 250 empresas e instituiçóes dos setores de Tecnologia da Informação e Comunicação (TIC) e de Economia Criativa (EC). 
restaurantes e boates atendendo uma elite consumista. Ali também circulam funcionários de conglomerados empresariais e de órgãos públicos, turistas que visitam equipamentos culturais, habitantes da Comunidade do Pilar que resistem à gentrificação ${ }^{6}$, bem como jovens e adultos que frequentam espaços ditos "alternativos" e manifestam suas opiniōes através da grafitagem em áreas abandonadas.

Para Harvey (2014), esses jovens e adultos merecem uma atenção especial, pois suas pautas - que passam pelo direito à moradia, pela gentrificação, pela criminalização dos pobres e diferentes - constituem também a luta pela cidade que emana "[...] basicamente das ruas, dos bairros, como um grito de socorro e amparo de pessoas oprimidas em tempos de desespero." (p. 15).

É nesse ambiente das ruas do Recife Antigo que esse artigo encontra condiçóes possíveis de estudar a cidade e o urbano ${ }^{7}$ através da grafitagem, um campo de múltiplas produçóes espaciais presente nas metrópoles brasileiras contemporâneas.

A grafitagem é considerada como marcas feitas por pessoas que se apropriam de certos locais da cidade e fixam nos muros algumas expressóes e imagens que propiciam diversos tipos de interação em que a percepçáo se desloca para os domínios da imaginação, da ficção e da fantasia (HARVEY, 2005). Esses artistas, comumente chamados de grafiteiros, através da exibição de signos para a sociedade, criam uma estética própria que vai além das artes visuais, envolvendo também a música, a literatura, a moda e outras linguagens. Dessa forma, constata-se que a grafitagem pode assumir significados diversos, proporcionando um amplo debate sobre a multiplicidade de sentidos da realidade (HAMBURGUER, 2007).

Esse artigo, então, se propóe a discutir a produção visual de grafiteiros no Recife Antigo com o intuito de identificar como o grafite dialoga com questôes de pertencimento territorial, legitimidade e identidade.

A organização e análise dos grafites selecionados foram influenciadas pelo método cartográfico rizomático apresentado por Deleuze e Guattari (2000), tendo como lente de observação as discussões levantadas pelo geógrafo britânico David Harvey, em seu livro Cidades Rebeldes, sobre as resistências urbanas ao poder hegemônico do capitalismo na constituição das cidades.

6 O termo gentrificaçáo foi utilizado pela primeira vez por Ruth Glass em meados do século passado numa tentativa de descrever o processo de investimento, reabilitação e apropriação pela classe média assalariada londrina de um estoque de moradias e de bairros operários ou populares (NERY e CASTILHO, 2008). Atualmente, esse processo é comum em diversas partes do mundo, resultando, frequentemente, na expulsão dos setores populares e em um controle mais rigoroso da diversidade sociocultural ali existente (FRUGOLÍ JR., 2001; TRINDADE, 2011).

7 Para efeito desse estudo, as questóes envolvendo aspectos físicos da cidade serão tratadas como "da cidade" e aquelas pertinentes ao tecido social que habita a cidade, "do urbano". 
Nesse aspecto, é natural que a coerência teórico-metodológica ${ }^{8}$ do estudo em foco desague nas ideias principais do Tratado de Nomadologia também desenvolvido por Deleuze e Guattari (2000).

A seguir, o artigo é estruturado em quatro sessões. Após a problematização apresentada, há uma exposição das principais questôes levantadas por Harvey (2014) sobre o direito à cidade em um cenário em que as cidades são planejadas a partir dos interesses capitalistas em detrimento do bem estar social. Em seguida, há uma discussão sobre a grafitagem como arte urbana. $\mathrm{Na}$ terceira sessão, essas duas discussóes se entrelaçam: manifestaçóes de resistência na cidade através da grafitagem como uma típica ação da máquina de guerra diante do aparelho de captura do estado. Sob a inspiraçáo do método cartográfico rizomático, grafites do Recife Antigo foram fotografados, selecionados e organizados para serem analisados. Por fim, o artigo assume um caráter provocativo, de contínua reflexão, sinalizando possíveis caminhos de análise, jamais esgotando qualquer um deles.

\section{A CIDADE: o bem estar social ou os interesses do capital?}

Ao apresentar diversos movimentos sociais de resistência às práticas capitalistas que ocorrem pelo mundo, Harvey (2014), em seu livro Cidades Rebeldes, discute inicialmente o que Lefebvre cunhou como o direito à cidade, ou seja, "[...] uma idealizaçáo de um tipo totalmente novo de cidade a partir do repulsivo caos de um desenfreado capital globalizante e urbanizador." (p. 20). Discutir o direito à cidade como um direito atual passa a ser um significante vazio, pois dependerá diretamente de quem lhe vai conferir significado. Financistas e empreiteiros tem tanto direito de reivindicá-la, a partir de seus interesses, como desempregados e sem-teto.

Para Harvey (2014), o grande desafio é promover essa idealização num contexto cujos conceitos em vigência são individualistas, baseados na propriedade e coadunam com a lógica de mercado hegemônica liberal e neoliberal. $\mathrm{Na}$ sua ótica, os direitos à propriedade privada e às taxas de lucro se sobrepóem a todas as outras noçôes de direitos em que se possa pensar. "Nessas condiçôes,

8 A tentativa de promover diálogos entre teóricos de campos ideológicos distintos - marxistas como Harvey, Lefebvre e Lojkine com Deleuze e Guattari da lógica da diferença - é justificada mais pelas suas interseçôes do que pelas posiçôes contrárias. Deleuze e Guattari (2000) explicam que o Estado, através do processo de axiomatização, sempre atua em prol do capital. No campo do urbanismo, os teóricos marxistas aqui contemplados, defendem que, a partir da cidade industrial, o poder hegemônico estatal molda os espaços também a favor da prática capitalista. Outra possível interseção está na discussão sobre o direito à cidade (LEFEBVRE, 1991; HARVEY, 2014) que coaduna, inclusive, com o devir-cidade daqueles que se encontram em rota de fuga com o aparelho de captura do Estado. Dessa forma, as tessituras desse artigo buscam se restringir aos diálogos possíveis desses teóricos nos campos do urbanismo, da política e das artes. 
os ideais de identidade urbana, cidadania e pertença, de uma política urbana coerente, já ameaçados pelo mal-estar da ética neoliberal individualista, tornam-se muito mais difíceis de manter." (p. 49).

O debate sobre o direito à cidade deve ser entendido, então, não como algo que já existe, mas como um direito de reconstruir e recriar a cidade como um corpo político socialista com uma imagem totalmente distinta, "[...] que erradique a pobreza e a desigualdade social e cure as feridas da desastrosa degradação ambiental. Para que isso aconteça, a produçâo das formas destrutivas de urbanização que facilitam a eterna acumulação de capital deve ser interrompida" (p. 247). Nesse contexto, Lefebvre (1999) propõe uma revolução urbana. Em sua obra de mesmo título, o autor expóe a necessidade de redimensionar a presença do Estado na gestão da cidade, por considerar a predominância da lógica tecnocrática em detrimento da democracia. Propóe-se, entâo, um modelo de autogestáo, onde os cidadãos manifestem suas demandas e, coletivamente, pensem e definam a cidade que desejam. Nesse modelo, o desenvolvimento social ocupa lugar estratégico, superior ao econômico.

Ainda nessa discussão sobre o direito à cidade, ao contemplar o espaço urbano, destaca-se a racionalizaçáo dos burocratas estatais e tecnocratas com o intuito maior de facilitar a acumulação de capital e de favorecer as relaçôes dominantes de classe. Diversos autores alertam para o fato de o Estado muitas vezes adotar o discurso democrático, mas, na verdade, é a sua lógica tecnocrática que orienta as intervenções urbanas estatais e privadas (LEFEBVRE, 1991, 2001; LOJKINE, 1979; OLIVEIRA, 2009).

É nesse contexto que o poder público se divide entre os interesses da coletividade e aqueles das classes dominantes, nas quais estáo incluídos os empresários dos segmentos financeiro e imobiliário. Para Harvey (2014), cada vez mais, o aparato estatal só parece conceber o mundo em termos de negócios e empreendimentos. Dessa forma, destaca-se a forte relação de dependência entre o desenvolvimento do capitalismo e a urbanizaçáo da cidade. Tanto o capitalismo precisa da urbanizaçáo para absorver o excedente de produção que nunca deixa de produzir, como a urbanizaçáo precisa do capitalismo para produzir os excedentes de produção exigidos por ela mesma.

Focando no contexto brasileiro, Maricato (2013) expóe que compreender a cidade é um ponto fulcral para melhor desvendar a relação entre o Estado e o capital, porém, no Brasil, nem a esquerda a enxerga e não consegue vê-la como um ambiente de luta de classes, nem a direita a considera cuja atenção está na especulação imobiliária e no assalto ao orçamento público.

Para compreender a expansão do capital no cenário globalizado, Harvey (2014) detalha sua dinâmica ao explicar que o capitalismo sempre encontra novos meios de produção e de exploração dos recursos naturais. Isso coloca uma pressáo cada vez maior sobre o meio ambiente, para que se possam extrair 
matérias-primas necessárias, como também absorver os inevitáveis desperdícios e rejeitos.

As leis coercitivas que regem a concorrência também forçam novas tecnologias e formas de organização a entrar em operação o tempo todo, uma vez que os capitalistas com maior produtividade podem submeter os que usam métodos inferiores. As inovações definem novos desejos e necessidades, acelerando o tempo de giro do capital e a fricção da distância. Isso amplia o alcance geográfico em que o capitalista é livre para buscar maior oferta de mão-de-obra, matérias-primas e assim por diante, gerando novas configurações das cidades.

Para Velázquez e Cobos (2013), o processo de globalização introduz duas variáveis significativas no nível urbano. Por um lado, com as novas distâncias impostas pela cidade, há a introdução de novas modalidades de cultura domiciliar, incluindo o homework, o hábito de ver filmes em casa, receber comida pronta. Por outro lado, há o que De Mattos (2002) chama de "artefatos da globalização" com a policentralização, a polarização social, a segregação social e a fragmentação da estrutura urbana.

Atento a essas questóes, Harvey (2014) explica que o poder público frequentemente procura reorganizar as infraestruturas da cidade e a vida urbana com o objetivo de manter as populaçóes insatisfeitas sob controle. Mencionando Levebvre em $A$ Revolução Urbana, ele distingue esses espaços como heterotópicos e isotópicos. Os primeiros são caracterizados pela diferença, terreno fértil para os movimentos sociais, provocadores de estado de tensão, onde, sob esse ponto de vista, a grafitagem se insere como uma prática urbana. Os isotópicos são a ordem consumada e racionalizada do capitalismo e do Estado.

É nessa linha que Zorzo (2012) afirma que os grafites merecem a reflexão e um acolhimento crítico por servirem, exatamente, para problematizar o olhar no ambiente da cidade. Através da análise da arte de rua, é possível tematizar o fluxo do olho no espaço urbano e, devido à sua contemporaneidade, oferece uma diversidade de reaçóes e proposiçóes políticas sobre a visualidade urbana.

\section{A GRAFITAGEM REBELDE ': a arte como forma de expressão urbana}

Em diferentes épocas e partes do mundo, os muros das ruas são uma tela para uma comunicação essencialmente pública. A experiência urbana, a cultura, a cidade, as ruas estão repletas de estímulos visuais que vão se somando às

9 O uso do adjetivo "rebelde" na grafitagem aqui discutida não busca promover uma classificaçáo estanque e dicotômica, mas sim, relacionar com as teorias discutidas por Harvey (2014) em Cidades Rebeldes e por Deleuze e Guattari (2000) no Tratado de Nomadologia, bem como, delimitar a seleção dos grafites para a pesquisa. As grafitagens impressas em áreas demarcadas e consentidas pelo poder público no Bairro do Recife não foram utilizadas na pesquisa, apenas aquelas em que seus artistas não obtiveram prévio consentimento do Estado ou do proprietário do imóvel. 
memórias, percepções e experiências individuais e da coletividade social (RINK e METTRAU, 2010; ROSS, 2015; DE RUITER, 2015, COWICK; 2015).

Compreender o fenômeno da grafitagem passa pela compreensão da arte, da cidade e do urbano. Através de seus desenhos impressos em paredes e muros, identifica-se a presença da vida urbana, do cotidiano, dos problemas sociais, econômicos e políticos que povoam as mentes de artistas de rua e invadem o olhar de passantes. Nessa vertente, Bosco (2010) considera o grafite como um modo de apropriaçáo do espaço urbano, sendo considerado um ato de interação, produtor de sentidos e de significados sociais.

Para muitos, a grafitagem é reconhecida como a tatuagem da cidade que traz arte a espaços mortos. Para outros, por ser associada à resistência, à manifestação de uma minoria oprimida num mundo onde o poder do capitalismo dita as regras, a grafitagem é uma cicatriz que traz consigo marcas de luta, liberdade de expressão, uma provocação que visa impactar e fazer refletir. Há ainda aqueles que a consideram uma micose que se espalha desordenadamente pelos espaços livres da cidade, desafiando o poder público e a propriedade privada, mais associada à pichação.

Nesse sentido, sem estabelecer distinçóes com a grafitagem, Wainer (2005) considera que a pichação é uma arte provocativa, capaz de causar reação no espectador ao se deparar com o inesperado. A pichação se tornou um ato de intervir em algo já existente, provocando impactos e reaçóes, direcionando e alterando olhares para um fato ou lugar dentro da banalidade cotidiana (VAZ, 2013).

No Brasil, pichação e grafitagem tem conceituações bem distintas especificadas, inclusive, no âmbito legal. A Lei dos Crimes Ambientais $\mathrm{N}^{\circ}$ 9605/98, em seu artigo 65, legaliza o grafite em detrimento da pichação. A prática do grafite é permitida e náo constitui crime, desde que realizada com o objetivo de valorizaçáo do patrimônio público ou privado, mediante manifestação artística, com o consentimento do proprietário do bem privado ou com a autorização dos órgáos governamentais responsáveis pela preservação e conservação do patrimônio histórico e artístico nacional.

Maurício Villaça, um dos precursores da arte da grafitagem no Brasil, compartilha a ideia de que o grafite é também as garatujas que são feitas desde a mais tenra idade, os rabiscos e gravaçóes feitos em bancos de praça, banheiros, e até mesmo aqueles que surgem quando falamos ao telefone. Assim, também, a grafitagem que se difunde de forma intensa nos centros urbanos significa riscar, documentar, de forma consciente ou não, fatos e situaçóes ao longo do tempo. Refere-se a uma necessidade humana como, por exemplo, dançar, falar, dormir e comer (GITAHY, 1999).

Atualmente, o grafite adquiriu outros significados, dentre eles como sinônimo de Aerosol Art ou Street Art, uma expressão artístico-estética que 
se manifesta na rua com latas de spray, stencil ou a mão livre e é reconhecida pelo seu dinamismo, temporalidade e cores vibrantes (ELSTEIN, 2015). Sua manifestação realça a diversidade e a desigualdade no meio urbano, tendo a problematizaçáo como âmbito de sua criação (KP, 2001).

Suas imagens são capazes de desestabilizar a coesão social imposta pelo poder hegemônico que pasteuriza subjetividades e reprime diferenças. A coesão social - ou sua falta - é retratada, nesse contexto, pela divisão dos espaços no ambiente urbano. Por um lado, há um espaço oficial projetado pelo poder público ou pela iniciativa privada e construído sem levar em consideração o uso que os cidadãos dariam a ele. Por outro lado, um mesmo espaço pode ser considerado alternativo ou da diferença, uma vez que ele pode ser usado e inventado na medida em que o cidadáo o nomeia ou o inscreve.

Em complementação, o grafite pode provocar também um desaceleramento do passante para a observação ou contemplação da arte exposta, sendo considerado ainda uma oposição à velocidade, à aceleração, características presentes na contemporaneidade dos grandes centros urbanos.

Para Iverson (2008), o grafite é considerado, atualmente, uma arte plástica com um sistema simbólico possível de ser decodificado socialmente, diferenciando-se da pichação cujos autores produzem pouca simbolização e seus traços ou tags são como rabiscos sem sentido para a maioria dos pedestres. A pichação é uma violência dos socialmente excluídos e sua manifestaçáo vai de encontro ao pacto social. Ela os ajuda a acomodar relaçóes confusas e difíceis numa tentativa de harmonizar com o mundo (BOSCO, 2010; HUTSON, 2011). Os pichadores atuam em qualquer lugar que ofereça visibilidade à sua ação, independente do valor histórico ou social do local. Suas tags não são decodificadas pela sociedade, quando muito o reconhecimento desses sinais ocorre entre eles, os próprios pichadores.

Sob um outro olhar, João Wainer, repórter-fotógrafo considera a pichação uma forma legítima de arte que não pode ser ignorada ou classificada simplesmente como ilegal. Sua leitura para a pichação está voltada para a estética e o desenvolvimento de um estilo próprio que combina com "a cor do asfalto, o cinza dos prédios, o cheiro da fumaça que sai do escapamento dos ônibus, o barulho do motor, da buzina dos motoboys, da correria..." (WAINER apud Schultz, 2010, p. 101). Para o repórter, esse tipo de intervenção urbana vem a ser uma forma pacífica e legítima de protesto contra a violência das cidades: 
va na forma de assaltos, sequestros e crimes. O pichador faz isso de uma maneira pacífica. É o jeito que ele encontrou de mostrar ao mundo que existe. (WAINER apud SCHULTZ, 2010, p. 101).

Aqui a arte, como modo de pensamento, deve deixar no caminho o senso comum e abrir o campo afetivo de forças que atacam com violência, uma desestabilização que arrasta ao limite das faculdades perceptivas entrando em uma dissonância que excita e embaralha. Esta abertura da arte por fora do reconhecimento e da imitação tende a um exterior inapreensível, intensamente produtivo de encontros singulares, múltiplos e indefinidos (DIAZ, 2014).

Em complementação, o especialista na obra de Gilles Deleuze, o filósofo canadenseAlain Beaulieu, em seu livro "Cuerpo y acontecimiento. La estética de Gilles Deleuze", afirma que Deleuze considera a arte como um meio privilegiado de resistência frente ao presente. O desafio estético deleuziano consiste em experimentar as obras em sua singularidade, situando-se o mais próximo possível do processo vital que a originou. Em outras palavras, Deleuze náo busca identificar o belo ou interpretar o sentido das obras, mas experimentar a vida não orgânica das forças impessoais comuns às sensaçôes daquele que experimenta e das próprias obras de arte. Essas linhas demarcatórias permitem identificar duas das características principais da estética deleuziana: a busca da imanência e a experimentação das forças. $\mathrm{O}$ estudo deleuziano das sensações responde a estas modalidades específicas (CHACÓN e LUTEREAU, 2012).

Em Mil Platôs, Deleuze e Guattari (2000) explicam que o espaço criativo é mais rico quanto mais mutável for, quanto mais se permitir a mudança, a migração, a fuga de um território e a reintegração de outros, um livre contraponto. No entanto, às vezes, se exagera operando com uma confusão de conceitos e sons. Em vez de produzir uma máquina cósmica, capaz de gerar um criativo sólido, se constrói, então, uma interferência que mistura os sentidos e as ideias. É apostando nessa complexidade que se ampliam os horizontes simbólicos (DIAZ, 2011).

Nesse campo de interpretaçôes, a grafitagem rebelde aqui exposta é aderente aos movimentos da máquina de guerra em permanente tensão com o aparelho de captura do estado discutidos por Deleuze e Guattari (2000) no Tratado de Nomadologia. Para os autores, o paradigma da máquina de guerra é uma potência de metamorfose que tenta romper os axiomas limitantes ofertados pelo aparelho de captura de estado, considerado uma máquina social capitalista com seu aparelho de repressão edipiano. Enquanto o Estado busca uma fixidez, retendo movimentos descodificados, o outro está em oposição, constantemente gerando novas subjetividades, fluxos de desejos (CROGAN, 2008; ONETO, 2010). 
No caso do grafite, percebe-se o esforço do Estado em ofertar aos grafiteiros, áreas demarcadas na cidade para a exposição de sua arte. As ruas têm, então, uma arte adestrada, domesticada, que não entra em confronto com o ofertante. O Estado produz um axioma através da concessão de espaços públicos onde o grafite ali exposto serve mais como um ornamento para contemplação dos passantes do que como provocação para uma reflexão social.

O grafite que invade espaços abandonados da cidade traz consigo o elemento da exterioridade ao paradigma do aparelho de estado. Ele é desordenado como o próprio ato de pensar e traz consigo uma outra ordem, outra natureza caracterizada pelo efêmero, que problematiza, busca experimentaçóes e se opóe ao hegemônico.

\section{O MÉTODO CARTOGRÁFICO RIZOMÁTICO}

O método cartográfico rizomático é apresentado por Deleuze e Guattari (2000) no volume 1 do livro Platôs: capitalismo e esquizofrenia. Para explicá-lo com sua aplicabilidade no campo da arte, faz-se oportuno discutir separadamente a ideia de cartografia para, em seguida, acrescentar a ideia de rizoma. Por fim, são detalhados os procedimentos metodológicos adotados na pesquisa.

Caracterizando-se pelo livre criar, a cartografia acompanha movimentos, podendo fazer seus próprios desvios. Concebe mapas, diagramas, territorialização e desterritorialização, reunindo um conjunto de cores, sentidos e intensidades, percorrendo espaços ainda náo visitados. Os mapas, objeto da cartografia, também podem ser pensados na ordem da estética, conectáveis e modificáveis que se prestam a interpretaçóes poéticas, incorporando valores culturais e crenças políticas ao figurarem e reconfigurarem o espaço:

[...] o mapa é aberto, é conectável em todas as suas dimensôes, desmontável, reversível, suscetível de receber modificações constantemente. Ele pode ser rasgado, revertido, adaptar-se a montagens de qualquer natureza, ser preparado por um indivíduo, um grupo, uma formação social (DELEUZE e GUATTARI, 2000, p. 21).

A cartografia é um método utilizado no campo da arte e da filosofia como pressuposto à investigação em poéticas visuais. Em sua origem, ela é a ciência que trata da concepção, produção, difusão, utilização e estudo dos mapas. Através da invençáo de mundos e seus lugares, da interpretaçáo do espaço, ela pode ser aplicada como método de acompanhamento para traçar percursos poéticos, sendo aquilo que força a pensar e ver o todo do processo do artista, dando-se como possibilidade de caminho a ser desenhado no trabalho, como uma atençáo voltada ao processo em curso (MOURA e HERNANDEZ, 2012). 
Entendendo, então, que o método cartográfico convida o pesquisador a um exercício cognitivo peculiar, traçando um campo problemático, ele requer um conhecimento muito mais capaz de inventar o mundo, ao invés de simplesmente reconhecê-lo. Seu esforço consiste em suscitar problemas, possibilitando identificar os termos nos quais eles se colocam. Para isso, mexe-se, revolve-se e tira o pensamento do lugar. Sua base está no desassossego, no agito de interações violentas com o pensamento e a formação de novos mundos (OLIVEIRA e PARAÍSO, 2012).

De acordo com Moura e Hernandes (2012), a cartografia repensa o funcionamento que rege as pesquisas, se aventurando, desnovelando investigaçóes, acontecendo de uma maneira que não tem regras a seguir. Ela é um movimento atencional, concentrado na experiência, na localização de pistas e de signos do processo em curso. Nesse caso, ela náo está relacionada à cartografia ligada aos estudos da geografia, a partir de traçados de conhecimentos precisos, fundado em bases matemáticas, estatísticas e que conta com instrumentos e técnicas sofisticadas (FILHO e TETI, 2013).

Para a arte, a cartografia é a experimentação do pensamento ancorado no real, é a experiência entendida como um saber-fazer, isto é, um saber que emerge do fazer (KASTRUP, 2010), com base no processo em que o conhecimento é construído através da atenção que configura o campo perceptivo. $\mathrm{O}$ sentido da cartografia é de acompanhamento de percursos, aplicação em processos de produção, conexóes de rede ou rizomas. Associar à cartografia a ideia de rizoma é atestar o pensamento na sua força performática, cuja pragmática está inteiramente voltada para uma experiência ancorada no real (DELEUZE e GUATTARI, 2000).

Deve-se considerar o aspecto subterrâneo de uma formação rizomática, que leva a um problema de visibilidade imediata dessa complexa e intrincada teia de relaçóes. Nesse sentido, Deleuze e Guattari (2000) expóem que tal formação rizomática tem como um dos princípios a cartografia/decalcomania indicando que o rizoma resiste à aplicaçáo do modelo estrutural-gerativo, opondo-se a quaisquer noçóes de eixo genético ou de estrutura profunda. $\mathrm{O}$ modelo árvore-raiz reproduz em série os decalques de um campo, uma situação, uma paisagem, enquanto o olhar rizomático traça uma cartografia, desenhando um mapa como diagrama variável (FILHO e TETI, 2013).

Para facilitar a compreensão de rizoma, Deleuze e Guattari (2000) ainda o explicam a partir de seis princípios. Dois deles já foram apresentados acima: a cartografia e a decalcomania. A seguir, a Tabela 1 identifica todos de forma sintética. 
Tabela 1: Características aproximativas de um rizoma.

\section{PRINCÍPIOS}

\section{DESCRITIVO SINTÉTICO}

Qualquer ponto de um rizoma deve ser conectado a outro. Cada traço não remete necessariamente a um traço linguístico: cadeias semióticas de toda natureza são aí conectadas a modos de codificação muito diversos, cadeias biológicas, políticas, econômicas etc. Um rizoma não cessaria de conectar cadeias Da conexão e da heterogeneidade semióticas, organizaçóes de poder, ocorrências que remetem às artes, às ciências, às lutas sociais. Uma cadeia semiótica é como um tubérculo que aglomera atos muito diversos, linguísticos, mas também perceptivos, mímicos, gestuais, cogitativos: não existe língua em si, nem universalidade da linguagem, mas um concurso de dialetos, de patoás, de gírias, de línguas especiais. Não existe locutor-auditor ideal, como também não existe comunidade linguística homogênea.

\section{PRINCÍPIOS DESCRITIVO SINTÉTICO}

As multiplicidades são rizomáticas e denunciam as pseudomultiplicidades arborescentes. Inexistência, pois, de unidade que sirva de pivô no objeto ou que se divida no sujeito. Inexistência de unidade ainda que fosse para abortar no objeto e para "voltar" no sujeito. Uma multiplicidade não tem nem sujeito nem objeto, mas somente determinaçôes, grandezas, dimensões que não podem crescer sem que mude de natureza (as leis de combinação crescem então com a multiplicidade). Os fios da marionete, considerados como $\mathrm{Da}$ rizoma ou multiplicidade, não remetem à vontade suposta multiplicidade uma de um artista ou de um operador, mas à multiplicidade das fibras nervosas que formam, por sua vez, outra marionete, seguindo outras dimensôes conectadas às primeiras. Os fios ou as hastes que movem as marionetes seriam chamados de trama. Um agenciamento é precisamente esse crescimento das dimensóes em uma multiplicidade que muda necessariamente de natureza à medida que ela aumenta suas conexóes. Não existem pontos ou posições em um rizoma como se encontra em uma estrutura, uma árvore, numa raiz. Existem somente linhas. 


\section{PRINCÍPIOS DESCRITIVO SINTÉTICO \\ Um rizoma pode ser rompido, quebrado em um lugar qualquer, e também retoma segundo uma ou outra de suas linhas e segundo outras linhas. É impossível exterminar as formigas, porque elas formam um rizoma animal do qual a maior parte pode ser destruída sem que ele deixe de se reconstruir. Todo rizoma compreende linhas de segmentaridade segundo as quais ele é estratificado, territorializado, organizado, significado, atribuído, etc.; mas compreende também linhas de desterritorialização pelas quais ele foge sem parar. Há ruptura \\ Da ruptura a-significante no rizoma cada vez que linhas segmentares explodem em uma linha de fuga, mas a linha de fuga faz parte do rizoma. Essas linhas não param de se remeter uma às outras. É por isso que não se pode contar com um dualismo ou uma dicotomia, nem mesmo sob a forma rudimentar do bom e do mau. Faz-se uma ruptura, traça-se uma linha de fuga, mas corre-se sempre o risco de reencontrar nela organizaçóes que reestratificam o conjunto, formaçóes que dão novamente o poder a um significante, atribuiçóes que reconstituem um sujeito. Como é possível que os movimentos de desterritorializaçáo e os processos de reterritorialização não fossem relativos, não estivessem em perpétua ramificação, presos uns aos outros?}

\section{PRINCÍPIOS}

Da cartografia e da decalcomania

\section{DESCRITIVO SINTÉTICO}

O rizoma é estranho a qualquer ideia de eixo genético ou de estrutura profunda que tem os princípios de decalque reprodutíveis ao infinito. Toda lógica de árvore é uma lógica do decalque e da reprodução. Diferente é o rizoma, mapa e não decalque. Fazer o mapa, não o decalque. A orquídea não reproduz o decalque da vespa, ela compóe um mapa com a vespa no seio de um rizoma. Se o mapa se opóe ao decalque é por estar inteiramente voltado para uma experimentação ancorada no real. $\mathrm{O}$ mapa não reproduz um inconsciente fechado sobre ele mesmo, ele o constrói. Ele contribui para a conexão dos campos, para o desbloqueio dos corpos sem órgáos, para sua abertura máxima sobre um plano de consistência. Ele faz parte do rizoma. O mapa é aberto, é conectável em todas as suas dimensóes, desmontável, reversível, suscetível de receber modificações constantemente. Pode-se desenhá-lo em uma parede, concebê-lo como obra de arte, construí-lo como uma açáo política ou como uma meditação. Uma das características mais importantes do rizoma talvez seja a de ter sempre múltiplas entradas; a toca, nesse sentido, é um rizoma animal, 
PRINCÍPIOS

DESCRITIVO SINTÉTICO

e comporta às vezes uma nítida distinção entre linha de fuga como corredor de deslocamento e os estratos de reserva ou de

Da cartografia e da decalcomania habitação (cf. por exemplo, a lontra). Um mapa tem múltiplas entradas contrariamente ao decalque que volta sempre "ao mesmo”. Um mapa é uma questão de performance, enquanto o decalque remete sempre a uma presumida "competência".

Fonte: Deleuze e Guattari (2000).

Para a produção desse artigo, sob a inspiração do método cartográfico ${ }^{10}$, foram fotografados os grafites desenhados nas ruas que vão da Rua Tomazina à Travessa do Amorim no extremo sul do Bairro do Recife Antigo ${ }^{11}$. Ao todo, foram realizadas quatro visitas ao local entre os dias 23 de junho e 15 de agosto de 2015. Na primeira, houve a coleta das imagens, fotografando todos os grafites encontrados. Cada imagem correspondia a um grafite, respeitando os limites, tantas vezes difusos, entre as produçóes artísticas.

Das 47 imagens coletadas, 11 foram selecionadas por apresentarem, mais explicitamente, questóes levantadas nas discussóes de David Harvey sobre o poder contra-hegemônico ao capital na formação das cidades, evidenciando o traço problematizador da vida cotidiana em centros urbanos, típico da grafitagem (GITAHY, 1999; KP, 2001; WAINER, 2005; VAZ, 2013).

Para a composição dos mapas, houve mais três visitas em diferentes horários com o objetivo de observar os grafites e senti-los em diferentes contextos. A segunda visita foi numa terça-feira à tarde, quando o bairro era frequentado prioritariamente pelos moradores da Comunidade do Pilar e pelos funcionários das repartiçóes públicas e de empreendimentos privados. A terceira observação foi no sábado à noite com os bares e boates abertos atraindo jovens e adultos para aquela redondeza. A última visita foi feita numa manhã de domingo, quando famílias frequentavam o Recife Antigo para atividades de lazer.

Com a seleção dos 11 grafites, foram compostos 4 mapas, considerando:

- o princípio da cartografia/decalcomania, em que atributos como imprevisibilidade e inevitabilidade que compreendem a lógica da diferença foram fundamentais para a adoção do método de matriz cartográfica rizomática (DELEUZE e GUATARRI, 2000);

10 Caracterizado como um estudo preliminar, buscou-se aqui seguir apenas algumas diretrizes apresentadas por Deleuze e Guattari (2000) sobre o método cartográfico rizomático. À medida que os grafites de novas áreas do Recife Antigo sejam incorporados ao estudo, pretende-se ampliar em rigor o método, adotando, em maior integridade, os seus procedimentos analíticos.

11 Para esse artigo, foram selecionados os grafites presentes no Polo Alfândega/Madre de Deus. Com a ampliação da pesquisa, serão incorporados os grafites dos Polos Bom Jesus, Pilar, Capibaribe e Arrecifes. 
- a disposição territorial dos grafites, observando a sua relação com aspectos históricos, políticos e sociais da localidade;

- uma coerência nas mensagens transmitidas pelos grafites, tanto explicitamente através de frases, como também nas imagens desenhadas;

- a compreensão de que também se evidencia na cidade um campo de luta anticapitalista com pautas específicas (HARVEY, 2014);

- a consciência de que os grafites espalhados pelos muros, assemelhados aos rizomas, são impossíveis de serem modelados, de seguir estruturas ou assumir pontos específicos (EL KHOURI, 2009).

Para a análise dos dados coletados, foram consideradas as categorias de análise a partir de três linhas (GONÇALVES, 2007) que compóem o rizoma e facilitam a operacionalização do método em foco:

- Linhas moleculares: são flexíveis e atravessam tanto sociedades como grupo de indivíduos. Elas possibilitam o afetamento da subjetividade criando zonas particulares de indeterminaçáo capazes de possibilitar agenciamentos.

- Linhas de fuga: presentes no espaço liso, estão no plano de imanência do desejo e convergem em processos que conduzem para o novo, novos modos de ser, pensar e agir. Elas são associadas ao processo de desterritorialização e de fluxos descodificados, capazes de gerar precipitaçóes e rupturas. Tais linhas com suas velocidades constituem agenciamentos.

- Linhas molares: remetem ao espaço estriado, operando a organização, as classes (gênero, sexo etc.) os estratos sociais (a família, a escola, o trabalho, etc.). Elas sempre classificam e sobre-codificam os sujeitos. Sáo caracterizadas pelo controle e aprisionamento que atravessam sociedades inseridas no sistema capitalista de produção. São linhas de viscosidade e de retardamento relativo.

Dessa forma, a seguir, são apresentados esboços incompletos, no máximo traços cartográficos que norteiem um pensamento, indiquem caminhos, expressem algo por vir, um devir. Dessa forma, assim como defende Williams (2013), em um constante exercício, as grafitagens podem ser revistas, rediscutidas, ressignificadas a cada novo olhar, rompendo representaçóes, apropriando-se de conceitos para criar algo novo, buscando diferenças. 


\section{A GRAFITAGEM NO RECIFE ANTIGO}

Figura 2: Mapa 1.

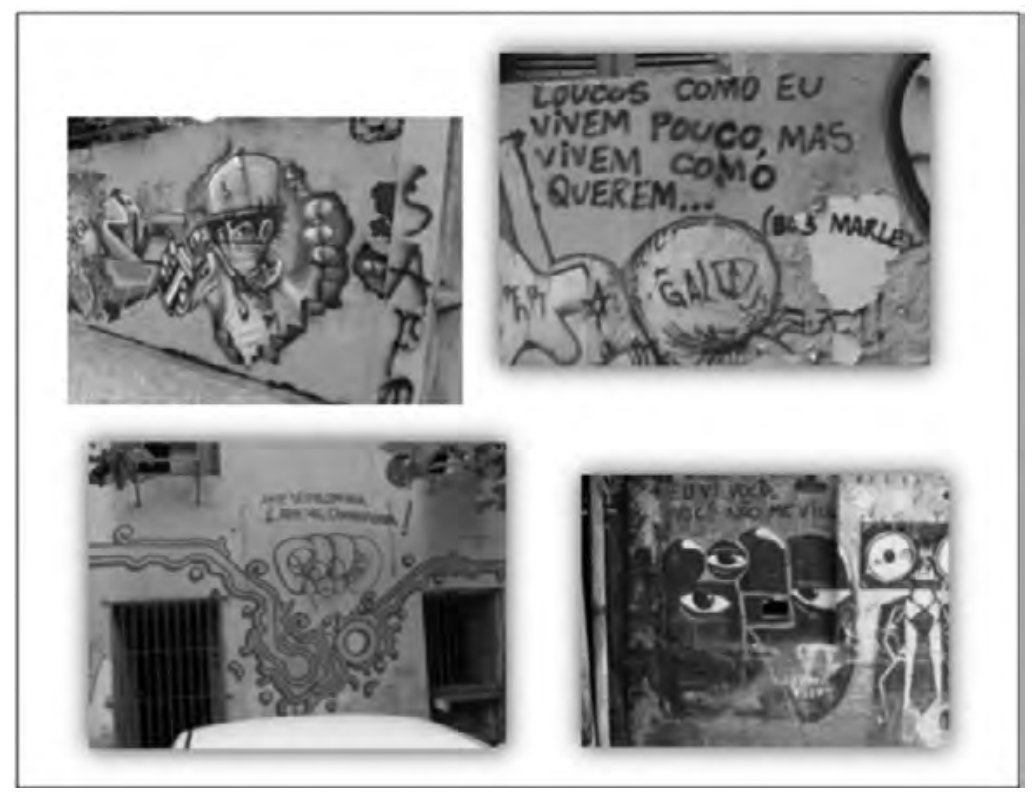

Fonte: Os autores, 2015.

Inicialmente, são apresentados aqui 4 grafites (Figura 2) que remetem à estética particular da grafitagem. Através do autorretrato de um grafiteiro em que parte do rosto é coberta, numa possível tentativa de não identificação, o artista surge do buraco do muro e impóe sua arte mesmo sem prévia autorização do uso do espaço. Esse buraco remete às fissuras da sociedade onde as manifestaçôes de injustiça e descontentamento precisam emergir. O spray é arma e a arte, violência, desestabilização, desconforto (DIAZ, 2014).

$\mathrm{Na}$ prática, isso já se percebe no caso da grafitagem. Com uma atuação isotópica e axiomática que busque a ordem e o uso racional do espaço, o Estado, por meio de linhas molares, demarca e autoriza espaços públicos para essa produção artística, promovendo certames públicos com temáticas pré-definidas, tantas vezes distantes de assuntos polêmicos e conflituosos. A mesma ação é feita pelo capitalismo quando a arquitetura de interiores, por exemplo, contrata grafiteiros para pintarem, sob encomenda, em paredes de escritórios, salas e quartos residenciais. Nesse caso, restabelece-se uma ordem e atenua os aspectos provocadores e tensionantes próprios da arte da grafitagem.

O boné e o casaco são trajes típicos de identificação de uma tribo, o pertencimento ao grupo. Normalmente, a sociedade considera os grafiteiros como aqueles que transgredem regras, loucos que possuem um comporta- 
mento libertário (MERRILL, 2015; BAKER, 2015). Isso pode ser exemplificado no grafite inscrito com a citação de Bob Marley (Figura 2). Sua arte "obscura", de produção "sorrateira", é incompreendida por muitos e totalmente ignorada por tantos, inclusive por outros profissionais atuantes no campo da cultura.

Uma vez os grafismos gerando incômodo ao sistema, devido ao seu caráter de ilegalidade, transgressão e tentativa de dar voz àqueles que, intencionalmente, são pouco ouvidos nas decisôes da polis, o Estado compreende que eles precisam ser apreendidos, capturados, codificados em seu território estriado. A arte urbana, entáo, representa - ainda em sua maioria - uma classe artística que está fora das redes aprisionadoras do sistema.

Nesse sentido, Deleuze e Guattari (1993), ao explicar a atuação do Estado no Tratado de Nomadologia, empenham uma atenção especial à sua relação com aquela sociedade que está fora de seu território de domínio, de controle, demandando-lhe um esforço de apreensão de fluxos, por meio de seu aparelho de captura. Isso é narrado logo no Axioma I do Tratado de Nomadologia cujo título é "A máquina de guerra é exterior ao aparelho de Estado".

Resgatando as metáforas sobre a grafitagem, tanto a tatuagem, como a cicatriz ou a micose representam a manobra no terreno liso, a linha molecular,ou seja, o risco sobre a pele, o corte no tecido social. Nesse caso, sua proposta é romper com a estabilidade, a uniformidade e o padrão estético, chamando a atenção do olhar, provocando inquietudes. Essas novas subjetividades são produzidas em situaçóes em que a máquina de guerra encontra espaços e tempos lisos, capazes de produzir relaçôes afetivas que não são firmadas por um centro racional ou político, mas sim, por um paradigma da criação e da ação contínuas (DELEUZE e GUATTARI, 2000). Isso pode ser materializado pela não-censura, pelo engajamento por saídas, pelo desbloqueio. É também o devir de minorias que estão em disputas historicamente.

Por ser uma street art, ela interage constantemente com o meio e produz sensaçóes e sentidos diversos a partir disso. A luminosidade - sendo dia com sol, nublado com chuva ou noite com a luz dos postes - produz novas sombras no grafite. A chuva acentua cores, a umidade traz lodo, brota plantas nas frestas dos muros e interage com a arte. Além disso, a grafitagem se expande até onde os muros permitirem, invade janelas, portas e dialoga com grades. $\mathrm{O}$ fato de não ter molduras e dobrar esquinas contribuem para a sensação de estar inacabada, um eterno devir (ABREU, 2010).

Diante da velocidade dos passantes, tantas vezes apenas centrados apenas em seu destino, a arte de rua pode ser vista, mas não percebida. Mesmo assim, eles, apenas pelo passar, experimentam e influenciam essa arte. No Recife Antigo, diferentes públicos transitam por esse território: o turista desavisado, os jovens em tribo, os desabrigados, os empregados da localidade. Cada 
um impóe o seu olhar e, ao mesmo tempo, uma vez sendo visto passando ou parado diante do grafite, ele também está emitindo novos significados a outros olhares que ali circulam. Isso resgata a autonomia da arte defendida por Deleuze e Guattari em que, uma vez criada, não depende nem do seu criador nem do espectador. A não-presença de um vínculo de autoria, de contextualização ou da experiência são capazes de libertar a grafitagem da prisão do estilo, do olhar, da história.

Figura 3: Mapa 2.

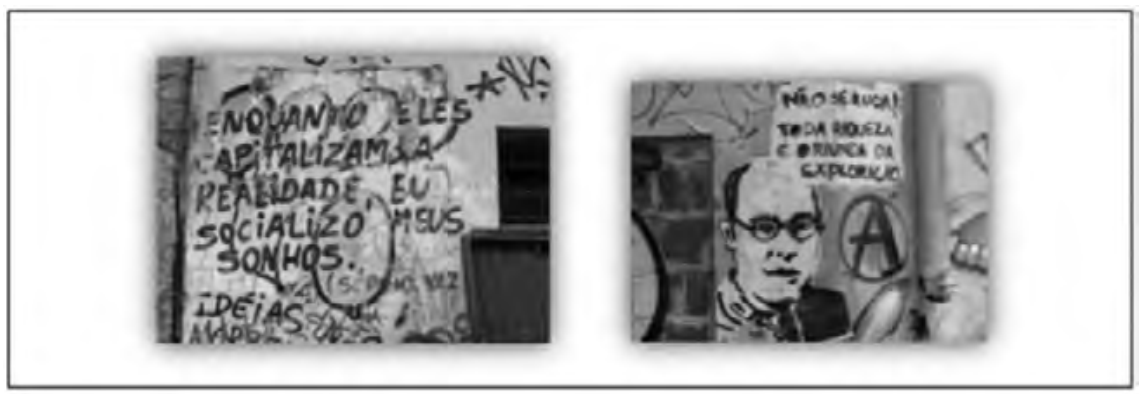

Fonte: Os autores, 2015.

Aqui, a grafitagem assume os papeis onírico e esclarecedor. No primeiro (Figura 3), o sonho não desaparece face à opressão daqueles que capitalizam a realidade. Pelo contrário, ele é potencializado quando pode ser socializado em paredes e muros. No segundo grafite, a mensagem é um alerta e esclarece uma das bases do sistema capitalista com a geração de riqueza oriunda da exploração. Ao lado (Figura 3), há o "A" circulado, marca identitária do movimento anarquista ${ }^{12}$.

Percebe-se que a discussão sobre os efeitos danosos do capitalismo nas cidades é recorrente. Em contribuição, a grafitagem surge como uma resistência às estratificaçóes sociais, privatização do espaço público, condiçóes negligenciadas de cidadania entre outros. A grafitagem rompe hegemonias, permitindo que os pensamentos, sonhos e ideais daqueles que vivem sob um regime econômico de opressão sejam registrados publicamente. É uma crítica extra-muros ao capitalismo, em sua essência, na mais valia, onde há a exploraçấo do trabalho pelo capital, gerando lucro e divisão de classes.

Com isso, a periferia invade o centro do Recife, de maneira impositora, tornando difusa as fronteiras espaciais do subúrbio e do centro, num mundo capitalista. É a voz do oprimido, do excluído do padrão vigente de sociedade.

12 Constitui uma ideologia surgida em meio aos movimentos populares das classes dominadas na segunda metade do século XIX e que visa, desde então, a partir de determinadas críticas, proposiçóes e estratégias, impulsionar um processo determinado de transformação social. 
A grafitagem se torna a manifestação daquele que não pode adquirir, possuir e consumir bens e, em compensaçãa, consome espaços ociosos e grita através de sua arte.

Para Harvey (2014), os movimentos sociais urbanos - assim como a grafitagem - são constantemente interpretados como algo, por definição, subordinado às lutas de classe, podendo ser mero desdobramento ou desvio da causa primária. Eles são anticapitalistas cujas raízes estão na exploração e alienação do trabalho. Muitas vezes, tais movimentos são originados "[...] do desespero que provém do sombrio desespero da marginalização, da repressão policial e da juventude ociosa perdida no puro tédio do aumento do desemprego e do desleixo nos subúrbios sem alma que terminam por se transformar em redutos de ruidosa rebeldia." (HARVEY, 2014, p. 12).

Nesse sentido, o grafite se opóe à opressão e à atuação seletiva do poder público. Para Deleuze e Guattari (2000), percebe-se um isomorfismo do Estado (do totalitário ao social-democrático) por sempre atuar a serviço do capitalismo. O que diferencia cada modelo, basicamente, é sua ação axiomática que vai da supressão de axiomas no totalitário até a multiplicação dos mesmos quando se deseja atender demandas sociais, estancando possíveis movimentos oposicionistas.

Lefebvre (1999), ao considerar a cidade como campo de disputa, disserta que esse cotidiano aprisionador é produto de uma sociedade terrorista controladora, manipuladora, que restringe as liberdades civis e que intervém na ação do Estado, orientando suas iniciativas na concepção de espaços, a partir de uma lógica tecnocrática.

De fato, esse olhar crítico e perturbador não pode ser desconsiderado, como também os reflexos negativos da modernidade na arte urbana, porém é evidente alertar para a necessidade de trazer novos olhares para o fenômeno urbano e perceber que, em um cenário em que o Estado e o capital ainda não aprisionaram todos os códigos sociais, ainda existem espaços vazios de produção rebelde em movimento, capazes de desestabilizar o cotidiano hegemônico, o poder instituído, as axiomatizaçóes e a passividade do cidadão contemporâneo (DUTRA, 2018). 
Figura 4: Mapa 3.

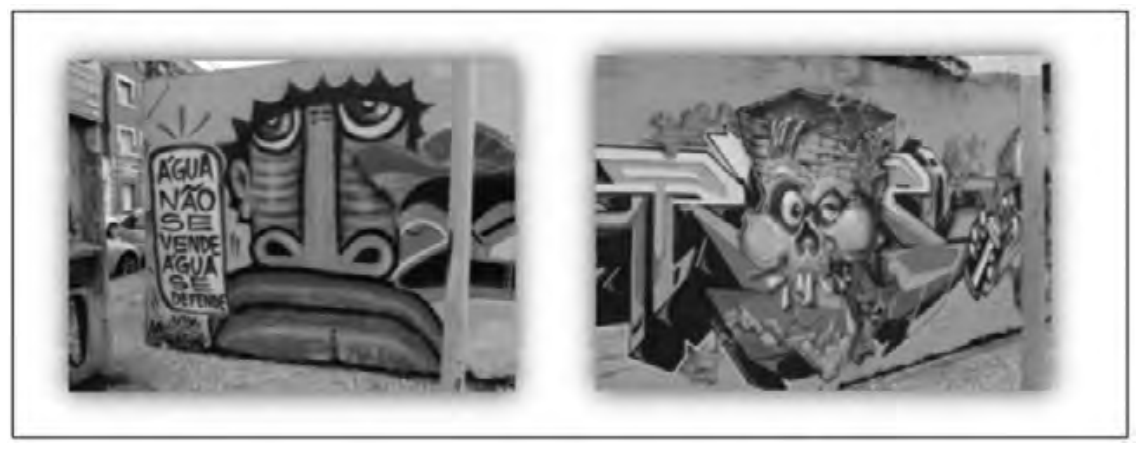

Fonte: Os autores, 2015.

Dois temas que retratam a precarização do urbano são contemplados nesse mapa (Figura 4). O primeiro está em constante evidência na mídia devido à seca que se alastra no país, em especial na região Sudeste. O uso sustentável dos recursos naturais como a água nunca foi táo discutido em sociedade. Isso remete a uma provocação que David Harvey explora sobre a apropriação do bem público, como a água, pelas grandes corporaçóes, uma prática capitalista segregadora que só permite o uso do recurso natural por aqueles que têm condiçôes de pagar pelo mesmo. Os custos da sua exploração desenfreada e inadequada normalmente são passados para o Estado que, numa relação de desigualdade e dependência para com as grandes corporaçóes, termina assumindo prejuízos com receio de futuras crises econômicas (HARVEY, 2004).

A segunda imagem desse mapa (Figura 4) traz uma caveira sem dentes com a caixa craniana de tijolos numa possível alusão às cidades concretadas, onde a natureza é substituída pelas construçóes, o que torna as cidades doentes. A localização desse grafite é defronte aos armazéns que foram reformados, abrigando atualmente bares e restaurantes de luxo. Para atender a esse público, a Prefeitura alterou o projeto de recuperaçáo do Polo Arrecifes e, onde seria uma praça arborizada, passou a ser a construção de estacionamento com dois pisos. Nesse caso, o grafite se torna espelho, refletindo quais são as prioridades do poder público, concretadas logo à frente. Em posiçôes opostas compondo o rizoma, o grafite se manifesta por meio de linhas moleculares e de fuga, enquanto a Prefeitura, em atuação pelo ordenamento público, atua em linhas molares, aprisionadoras. 
Figura 5: Mapa 4.

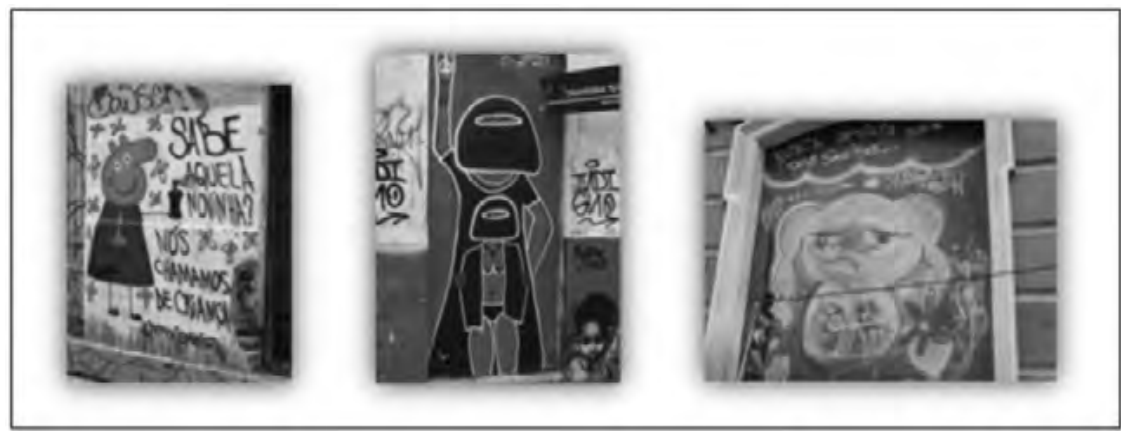

Fonte: Os autores, 2015.

Resgatando a história do Recife Antigo e identificado sua origem portuária, o bairro já teve momentos áureos seguidos de períodos decadentes. Muitas de suas ruas serviam de baixo meretrício onde a prostituição, bebidas e drogas eram ofertadas aos residentes e portuários que transitavam pelas suas vielas estreitas e pouco iluminadas. Atualmente, o território pesquisado resgata muitos desses atributos, onde cortiços são habitados por famílias que recorrem à prostituição como fonte de renda. Isso tem inspirado grafiteiros a provocarem tais questóes em suas artes. Nesse mapa (Figura 5), isso se faz evidente, em especial pela exploraçáo sexual de menores.

Tal exploração - de meninas nessa passagem - é um tema recorrente nas grafitagens do bairro. O primeiro (Figura 5) traz a personagem infantil Peppa Pig transmitindo uma mensagem sobre a banalização do assunto, quando abusar sexualmente uma "novinha" parece algo normal, distanciando-se do fato de ser uma criança. A segunda imagem refere-se também à prostituição de menores como um sinal de protesto em que um corpo de uma menor é exposto acompanhado de uma mulher, ambas com rostos velados em sinal de \#LUTO. Porém, apesar das adversidades, a esperança não está morta. $\mathrm{O}$ semblante triste da menina, na terceira imagem, é acompanhado do pedido de continuar perseguindo os seus sonhos, registrando que sempre é possível identificar espaços utópicos de esperança em meio ao caos (HARVEY, 2004).

Esses grafites (Figura 5), em especial o primeiro e o terceiro, por registrarem imagens infantis, permitem maiores variaçóes de sensaçóes. No domingo de sol, pais e filhos passam diante deles em suas bicicletas ou caminhadas, fazendo com que o grafite componha o cenário sem agressões. No caso da Peppa Pig, crianças posam em frente para registro fotográfico de seus pais desatentos às mensagens. À noite, esse mesmo local é frequentado por jovens e adultos. Poucas iluminaçóes aliadas ao rock e a dance music em alto volume dos bares e boates da localidade dão uma sensação totalmente oposta ao deparar-se com os grafites. O lúdico e infantil assumem, então, tons som- 
brios onde, mais do que as imagens, os textos que as acompanham se fazem coerentes. Aqui, os grafites também estão em harmonia com o cenário, porém com diferentes significados.

\section{CONSIDERAÇÓES FINAIS}

Ao discutir movimentos sociais e intervençóes urbanas anticapitalistas, Harvey (2014) elenca uma série de acontecimentos pelo mundo, desde os sucessivos movimentos revolucionários de Paris de 1789 a 1830 até açóes mais recentes na América Latina como os movimentos revolucionários em Oaxaca, no México, em Cochabamba (2000 e 2007) e EI Alto (2003 e 2005), na Bolívia, ao lado de manifestaçóes muito diferentes, mas igualmente importantes em Buenos Aires, de 2001 a 2002, e em Santiago do Chile (2006 e 2011). Todos eles deixam marcas não apenas na memória da sociedade, como também nos muros das ruas dessas cidades. A grafitagem pode ser considerada um efeito pictórico dessa história, cuja essência está nas lutas de classe de base urbana. Lutas que não se restringem a armas, mas que também envolvem a arte.

Portanto, é evidente que a cidade funciona como um espaço importante de ação e revolta política. As características atuais de cada lugar, sua engenharia física e social, bem como a organização territorial são possíveis armas nessas lutas políticas. Esses foram apenas alguns elementos para olhar as grafitagens aqui apresentadas.

Associar grafitagem com território e arte discutido por Deleuze e Guattari (1992) possibilita compreender a criação de um território como uma maneira instintiva, não racional de fazer arte. Para os filósofos franceses, não é um desenvolvimento de uma habilidade funcional, mas a criação de uma paisagem. Entende-se aqui a paisagem como o traço que compóe o território, dando-lhe um modo próprio de vida, criando linhas com as forças em movimento, revelando figuras. A arte, nesse caso, começa com o devir-animal, com a toca, onde não há causalidade ou finalidade na toca: agenciamento território-casa. Nesse sentido, um território é uma marcação intensiva, uma matéria de expressão que se dá nas posturas e nas cores do corpo, nos cantos e nos gritos (DELEUZE e GUATTARI, 1992).

A grafitagem pode, então, ser associada à metalurgia no Tratado de Nomadologia, quando a arte tanto pode ser um instrumento de arma-afeto para a máquina de guerra como um utensílio introceptivo para o aparelho de estado (ONETO, 2010). Compete ao metalúrgico, nesse caso o grafiteiro, agenciar seus desejos a depender dos seus objetivos: inquietar-se, romper, metamorfosear ou obedecer, atender e reprimir.

Dentro da cidade, entáo, direcionou-se o olhar para espaço público no Recife Antigo. Ali, percebe-se que o uso desse espaço assume inúmeras con- 
figuraçóes, onde cada uma delas possibilitaria novos estudos. As ruas, praças e calçadas do bairro tanto servem para o encontro de pessoas, constituindo uma sociedade mais forte, como também a convivência no espaço público melhora coletivamente a qualidade de vida. Em oposição ou complementação, esse espaço é também um ambiente de tensóes, conflitos e disputas por territorialidade. A arte da grafitagem e a violência urbana, cada uma à sua forma, denunciam os problemas acarretados pela priorização do Estado aos interesses do sistema capitalista sob o discurso da prosperidade, em detrimento do bem estar social.

O método cartográfico, como já discutido, possibilita, então, uma multiplicidade de entendimentos, interpretaçóes, conexôes e linhas que são inesgotáveis, incorporando valores culturais e crenças políticas para a configuração e reconfiguração do espaço. Mais do que esgotar os mapas, buscou-se o mínimo de coerência ao olhar, considerando os princípios do funcionamento rizomático.

Nessa perspectiva, compreende-se que os grafites, de fato, formam uma rede heterogênea, variável, acêntrica, aberta. A cada novo elemento em análise (o discurso dos grafiteiros, o olhar dos passantes, a interpretação do poder público, o entendimento de urbanistas entre outros), os mapas podem ter suas linhas rompidas ou quebradas para assumir novas configurações. $\mathrm{O}$ trabalho é contínuo e mutável a cada novo olhar, como tão bem explica Diaz (2011) ao mencionar a fuga pela representação em "O Rigor da Ciência" de Borges:

Não se deveria perder de vista, ainda, que qualquer abordagem da realidade sempre se opera a partir de uma perspectiva. Querer produzir mapas que evoquem as multiplicidades pode ser desastroso. Em "O Rigor da Ciência" Borges narra os esforços de todos os habitantes de um reino para fazer um mapa perfeito de seu país. A compulsão representativa os levou a estender tanto os limites desse mapa que finalmente alcançou as mesmas dimensôes do reino. Nesse momento, perdeu-se sua condição de mapa e tornou-se inútil e foi abandonado com o tempo. Quando uma criação se confunde com o que ela pretende aludir, ela perde o sentido. E o absurdo não é revertido pela saturação dos códigos, mas sim, através de um simples gesto, a rota de fuga.

\section{REFERENCIAS}

ABREU, O. F. A arte na filosofia de Deleuze. In: HADDOCK-LOBO, R. Os filósofos e a arte. Rio de Janeiro: Rocco, 2010.

BAKER, A. M. Constructing citizenship at the margins: the case of Young graffiti writers in Melbourne. Journal of Youth Studies, vol. 18, issue 8, p. 997-1014, Oct. 2015. 
BOSCO, F. A Lírica do Resto. O Globo, Rio de Janeiro, 06 out. 2010. Segundo Caderno, p. 01.

BRASIL. Lei № 9.605, de 12 de fevereiro de 1998. Diário Oficial da República Federativa do Brasil, Poder Legislativo, Brasília, DF, 13, fev. 1998, p.1. CAMPELO, R. Bairro do Recife em revitalização: desafios e perspectivas. Recife: Monumenta, 2008.

CHACÓN, P. E.; LUTEREAU, L. Alain Beaulieu: "Para Deleuze, el arte es un medio privilegiado de resistencia frente al presente". 2012.

Disponível em: <http://www.revistaenie.clarin.com/ideas/Beaulieu-Deleuze-Badiou_0_748125381.html>. Acesso em: 01 jul. 2015.

COWICK, C. Preserving Street Art: Uncovering the Challenges and Obstacles. Art Documentation: Bulletin of the Art Libraries Society of North America, v. 34, issue 1, p. 29-44. 2015.

CROGAN, P. Theory of state Deleuze, Guattari and Virilio on the state, technology and space. Angelaki: Journal of the Theoretical Humanities. v. 4, n. 2, p. 137-148, jun. 2008.

DELEUZE, G.; GUATTARI, F. Mil platôs - Capitalismo e esquizofrenia. São Paulo-SP: Editora 34. 2000.

O que é Filosofia? São Paulo: Editora 34, 1993.

DE MATTOS, C. A. "Mercado metropolitano de trabajo y desigualdades sociais en el Gran Santiago. Una ciudad dual?" Revista Eure, Santiago-Chile, v. XXVIII, n. 85, p. 51-70, dic. 2002.

DE RUITER, A. Imaging Egypt's political transition in (post-) revolutionary street art: on the interrelations between social media and graffiti as media of communication. Media, Culture \& Society, v. 37, issue 4, p. 581-601, mayo, 2015.

DIAZ, S. Arte y pensamiento en Gilles Deleuze. Una experiencia lúdico-estética más allá de la interpretación. Revista de Estética y Teoria de las Artes, n. 13, feb. 2014.

DIAZ, E. Gilles Deleuze y la arte de la fuga. 2011.

Disponível em: <http://biofiloart.blogspot.com.br/2011/03/gilles-del-e-uze-y-el-arte-de-la-fuga.html>. Acesso em: 01 jul. 2015.

DUTRA. H. "Se correr o bicho pega, se ficar o bicho come". A arte urbana dos grafismos e sua relação com a cidade de Sáo Paulo. Tese de doutorado, Universidade Federal de Pernambuco, Programa de Pós-graduação em Administração, 2018. 
EL KHOURI, M. M. Rizoma e educação: contribuições de Deleuze e Guattari. In: XV ABRAPSO, 2009, Maceió-AL. Anais do congresso. Maceió-AL, 2009.

ELSTEIN, A. Is it graffiti or street art? Crain's New York Business, v. 31, issue 24, p. 0026-0026. 2015.

FILHO, K. P. ; TETI, M. M. A cartografia como método para as ciências humanas e sociais. Barbaroi, Santa Cruz do Sul-RS, n. 38, p. 45-59, 2013.

FOLHA-PE. Arrastão, correria e disparos de arma de fogo assustam visitantes no Recife Antigo. 2015. Disponível em: <http://www.folhape.com.br/ $\mathrm{cms} /$ opencms/folhape/pt/cotidiano/policia/arqs/2015/01/0022.html>. Acesso em: 16 jan. 2015.

. Bairro do Recife é palco de brigas em mais um domingo. Disponível em: <http://www.folhape.com.br/cotidiano/2016/6/bairro-do-recife-e-palco-de-brigas-em-mais-um-domingo-0 05 .html>. Acesso em: 18 set. 2016.

FRUGOLI JR., H. A questão da centralidade em São Paulo: o papel das associaçóes de caráter empresarial. Revista de Sociologia e Política, Curitiba, n.16, 2001.

G1. Rua da Moeda, no Bairro do Recife, volta a ser ponto de tráfico e violência. 2014. Disponível em: <http://g1.globo.com/pernambuco/noticia/2014/12/rua-da-moeda-no-bairro-do-recife-volta-ser-ponto-de-trafico-e-violencia.html>. Acesso em: 16 jan. 2015.

G1. MPF pede que Prefeitura entregue casas no Pilar até 30 de setembro. Disponível em <http://g1.globo.com/pernambuco/noticia/2016/08/mpf-pede-que-prefeitura-entregue-casas-no-pilar-ate-30-de-setembro.html>. Acesso em: 18 set. 2016.

GITAHY, Celso. O que é graffiti. São Paulo: Brasiliense, 1999.

GIUSTINA, Leda Bernardi Della. O pilar que ficou: um estudo de conservaçáo em bens patrimoniais a partir do conceito de valor: o Caso da Igreja do Pilar do Recife. Recife, PE, 2010. Dissertação de mestrado, Universidade Federal de Pernambuco, CAC, Desenvolvimento Urbano, 2010.

HAMBURGER, Esther. Violência e pobreza no cinema brasileiro recente: reflexôes sobre a ideia de espetáculo. Novos Estudos CEBRAP. Sáo Paulo, n. 78, jul. 2007.

HARVEY, D. Espaços de Esperança. São Paulo: Edições Loyola, 2004. 
. Condição Pós-Moderna. São Paulo: Ediçôes Loyola. 2005.

. Cidades Rebeldes. Do Direito à Cidade à Revolução Urbana. São

Paulo: Martins-Fontes, 2014.

HUTSON, S. R. The art of becoming: the graffiti of Tikal, Guatemala. Latin American Antiquity, v. 22, Issue 4, p. 403-426, dec. 2011.

IVERSON, J. T. Onder Walls - Stencil Graffiti has Moved From Streets of Paris into Art books. Time - Global Adviser, USA, p. 61-62, 14 de Jun. 2008.

KASTRUP, V (org.). Pistas do método da cartografia: Pesquisa-intervenção e produção de subjetividade, Porto Alegre, Sulina, 2010.

KP, Juny. Elemento fundamental: arte grafite. 2001. Disponível em: <http:// www.graffiti.org/faq/elementos_br.html>. Acesso em: 07 jul. 2015.

LEAL, S. Fetiche da participaçáo popular: novas práticas de planejamento, gestão e governança democrática no Recife. Recife: Editora do autor, 2003.

LEFEBVRE, H. A vida cotidiana no mundo moderno. São Paulo: Ática, 1991.

. A Revoluçáo Urbana. Belo Horizonte: Editora UFMG, 1999.

O Direito à Cidade. São Paulo: Centauro, 2001.

LOJKINE, J. O papel do Estado na urbanização capitalista. FORTI, Reginaldo (Org.). Marxismo e urbanismo capitalista. São Paulo: Ciências Humanas, 1979.

MARICATO, E. Passe livre e as manifestaçóes que tomaram as ruas do Brasil. In: MARICATO, E. et al. Cidades rebeldes [recurso eletrônico]. São Paulo: Bomtempo: Carta Maior, 2013.

MERRILL, S. Keeping it real? Subcultural graffiti, street art, heritage and authenticity. International Journal of Heritage Studies, v. 21, issue 4, p. 369-389, apr. 2015.

MOURA, C. B.; HERNANDEZ, A. Cartografia como método de pesquisa em arte. 2012. Disponível em: <http://periodicos.ufpel.edu.br/ojs2/index. php/Arte/article/viewFile/1694/1574>. Acesso em: 14 jul. 2015.

NE10. Recife Antigo de Coraçáo atrai mais de $\mathbf{4 0}$ mil pessoas para o Bairro do Recife. 2014. Disponível : <http://entretenimento.ne10.uol.com.br/ turismo/noticia /2014/11/30/recife-antigo-de-coracao-atrai-mais-de-40-mil-pessoas-para-o-bairro-do-recife-522035.php> Acesso em: 15 dez. 2014. 
NERY, N. S.; CASTILHO, C. J. M. de. A comunidade do Pilar e a revitalização do bairro do Recife: possibilidades de inclusão socioespacial dos moradores ou gentrificação. Humanae, Recife-PE, v.1, n. 2, p. 19-36, dez. 2008.

. SÁ, A. J. A "modernidade" anunciada para o espaço de moradia dos pobres do bairro do Recife-PE. Revista de Geografia. Recife: UFPE DCG/NAPA, vol. 26, no. 3, set-dez. 2009.

Inclusáo socioespacial de comunidades pobres: programa de requalificaçáo urbanistica e inclusáo social da Comunidade do Pilar, Bairro do Recife-PE - Recife: o autor, 2012.

OLIVEIRA, E. F. Revitalizaçáo dos centros urbanos: a luta pelo direito à cidade. O autor: 2009.

OLIVEIRA, T. R. M; PARAÍSO, M. A. Mapas, dança, desenhos: a cartografia como método de pesquisa em educação. Pro-Posiçóes, Campinas, v. 23, n. 3 (69), p. 159-178, set/dez, 2012.

ONETO, P. D. A Nomadologia de Deleuze-Guattari. Lugar comum, n. 2324, p. 147-161, jun. 2010.

PREFEITURA MUNICIPAL DO RECIFE. Empresa de Urbanização do Recife - URB. Processo de revitalizaçáo do Bairro do Recife 1986-2001. Recife, nov.2001.

RECIFE ANTIGO DE CORAÇÃO. O projeto. 2013. Disponível em: $<$ http://www.recifeantigodecoracao.com.br/o-projeto.html>. Acesso em: 18 jan. 2015.

RINK, A.; METTRAU, M. B. Grafitagem: Resistência e criação. Revista Tamoios, Rio de Janeiro-RJ, ano VI, n. 1, p.76-90. 2010.

ROSS, J. I. Graffiti goes to the movies: American fictional films featuring graffiti artists/writers and themes. Contemporary Justice Review, v. 18, issue 3, p. 366-383, sep. 2015.

SANTOS, R. S.A. (re)ordenaçáo espacial do Bairro do Recife a partir da proposta do plano de revitalizaçáo turística. Porto Alegre, RS, 2010. Dissertação de Mestrado, Universidade Federal do Rio Grande do Sul, Instituto de Geociências, Programa de Pós-Graduação em Geografia, 2010.

TRINDADE, T. A. A luta pelo direito à cidade na América Latina: políticas de revitalizaçáo das áreas centrais e organizaçóes do movimento de moradia, 2011. Disponível em: <http://www.centrodametropole.org.br/ static/uploads/thiago_aparecido_trindade.pdf>. Acesso em 26 nov. 2015. 
VAZ. T. Pichação + arte + educação: outros olhares. Revista Digital do LAVSanta Maria-RS, ano VI, n.10, p. 85-97, mar. 2013.

VELÁZQUEZ, R. R. B; COBOS, E. P. Teorías sobre la ciudad en América Latina - Volume II. Cidade do México: Editores e Impresores Profesionales Edimpro S.A., 2013.

WAINER, J. Pichação é arte. Super Interessante, São Paulo-SP, n. 213, p. 98, $\mathrm{abr} / \mathrm{maio} 2005$.

WILLIAMS, J. Toward a theory of spatial justice.Annual Meeting of the Western Political Science Association Los Angeles, CA: 2013.

ZORZO, F. A. A visualidade urbana contemporânea como campo de estados interdisciplinares. In: CONGRESSO INTERNACIONAL INTERDISCIPLINAR EM SOCIAIS E HUMANIDADES, 2012, Niterói-RJ: ANINTER-SH/ PPGSD-UFF. Anais do congresso. Niterói-RJ, 2012. 
